\title{
Regulation of smooth muscle-specific gene expression by cGMP-dependent protein kinase
}

\author{
Tong Zhang, Raphaela Schwappacher, Shunhui Zhuang and Renate B Pilz*
}

\author{
Address: Department of Medicine University of California, San Diego, La Jolla, CA 92093, USA \\ Email: Renate B Pilz* - rpilz@ucsd.edu \\ * Corresponding author
}

from 4th International Conference of cGMP Generators, Effectors and Therapeutic Implications

Regensburg, Germany. 19-21 June 2009

Published: II August 2009

BMC Pharmacology 2009, 9(SuppI I):P79 doi:I0.II86/I47I-22I 0-9-SI-P79

This abstract is available from: http://www.biomedcentral.com/I47I-22 I0/9/SI/P79

(c) 2009 Zhang et al; licensee BioMed Central Ltd.

\section{Background}

Vascular smooth muscle cells (VSMCs) in normal adult blood vessels exhibit a differentiated, "contractile" phenotype, but in atherosclerotic disease and after acute vascular injury, they de-differentiate into a proliferative, "synthetic" phenotype; the latter is characterized by decreased smooth muscle (SM)-specific gene expression and decreased cGMP-dependent protein kinase (PKG) activity $[1,2]$. Prolonged in vitro culture of primary aortic VSMCs, or exposure of pulmonary VSMCs to hypoxia also leads to de-differentiation associated with loss of PKG, and restoring PKG activity increases SM-specific gene expression and re-differentiates cells into the contractile phenotype, but the mechanism(s) whereby PKG regulates SM genes are poorly understood $[2,3]$.

\section{Results}

Using siRNA-mediated down-regulation or pharmacologic inhibition of PKG, we recently showed that PKG is necessary for maintaining high SM-specific gene expression in differentiated VSMCs, and that PKG stimulation of SM-specific promoters requires serum response factor (SRF), the SM-specific transcription factor GATA-6, and the cysteine-rich LIM-only protein CRP4. Like other CRPfamily proteins, CRP-4 appears to act an adaptor protein, promoting the cooperation between SRF and GATA proteins on SM-specific promoters; PKG associates with CRP4 and phosphorylates the protein in intact cells. Phosphorylation-deficient, or PKG binding-deficient CRP4 mutants did not support cGMP/PKG stimulation of the SM- $\forall$-actin promoter. CGMP/PKG enhanced SRF binding to a SM- $\forall$ actin promoter CArG element in the presence of wild type, but not mutant CRP4. Chromatin immunoprecipitation assays showed that CRP4, SRF, and PKG associate with the CArG elements of endogenous SM-specific genes in intact cells. In the presence of CRP4, CGMP/PKG increased SRFand GATA6-dependent expression of endogenous SMspecific genes in pluripotent embryonal 10T1/2 cells.

Platelet-derived growth factor-BB (PDGF) is a key regulator of VSMC phenotypic modulation, and potently suppresses SM-specific gene transcription (1). We found that PDGF suppressed PKG expression in VSMCs, and that restoring PKG reversed PDGF inhibition of SM-specific genes without affecting PDGF activation of extracellular signal-regulated kinases (Erk-1/2) or phosphatidyl-inositol-3-kinase/Akt pathways. PDGF treatment or siRNAmediated down-regulation of PKG induced dissociation of SRF and CRP4 from SM-specific promoters, and PKG re-expression appeared to prevent these effects.

\section{Conclusion}

We conclude that PKG maintains SM-specific gene expression in differentiated VSMCs and prevents PDGF-induced down-regulation of SM-specific genes by facilitating assembly of CRP4/SRF complexes at SM-specific promoters; PKG modulates the adaptor function of CRP4 by phosphorylating CRP4, and may affect recruitment of SRF co-factors. 


\section{References}

I. Owens GK, Kumar MS, Wamhoff BR: Molecular regulation of vascular smooth muscle cell differentiation in development and disease. Physiol Rev 2004, 84:767-80I.

2. Lincoln TM, Wu X, Sellak H, Dey N, Choi CS: Regulation of vascular smooth muscle cell phenotype by cyclic GMP and cyclic GMP-dependent protein kinase. Front Biosci 2006, I I:356-67.

3. Zhou W, Dasgupta C, Negash S, Raj JU: Modulation of pulmonary vascular smooth muscle cell phenotype in hypoxia: role of cGMP dependent protein kinase. Am J Physiol Lung Cell Mol Physiol 2007, 292:LI459-66.

Publish with Bio Med Central and every scientist can read your work free of charge

"BioMed Central will be the most significant development for disseminating the results of biomedical research in our lifetime. "

Sir Paul Nurse, Cancer Research UK

Your research papers will be:

- available free of charge to the entire biomedical community

- peer reviewed and published immediately upon acceptance

- cited in PubMed and archived on PubMed Central

- yours - you keep the copyright

Submit your manuscript here:

http://www.biomedcentral.com/info/publishing_adv.asp 